\title{
LANDSCAPE OF THE MANGYSTAU REGION IN KAZAKHSTAN AS A GEOMORPHOTOURISM DESTINATION: A GEOGRAPHICAL REVIEW
}

\author{
Asima G. KOSHIM* \\ Al-Farabi Kazakh National University, Department of Cartography and Geoinformatics, \\ Al-Farabi Avenue 71, 050040, Almaty, Kazakhstan, e-mail: asima.koshim@gmail.com
}

\begin{abstract}
Aigul M. SERGEYEVA
K. Zhubanov Aktobe Regional State University, Department of Geography and Tourism, Moldagulova Ave 34, o3000o, Aktobe, Kazakhstan, e-mail:sergeyeva.aigul@gmail.com
\end{abstract}

Roza T. BEXEITOVA

Al Farabi Kazakh National University, Department of Cartography and Geoinformatics, 050040, al-Farabi ave., 71, Almaty, Kazakhstan, e-mail: Roza.Bexeitova@kaznu.kz

\section{Aliya S. AKTYMBAYEVA}

Al Farabi Kazakh National University, Department of Tourism, 050040, al-Farabi ave., 71, Almaty, Kazakhstan, e-mail: aliya.aktymbaeva@gmail.com

\begin{abstract}
Citation: Koshim A.G., Sergeyeva A.M., Bexeitova R.T. \& Aktymbayeva A.S. (2020). LANDSCAPE OF THE MANGYSTAU REGION IN KAZAKHSTAN AS A GEOMORPHOTOURISM DESTINATION: A GEOGRAPHICAL REVIEW. GeoJournal of Tourism and Geosites, 29(2), 385-397. https://doi.org/10.30892/gtg.29201-476
\end{abstract}

\begin{abstract}
One of the ideas of using landscape, that a section of terrain can be appreciated as an object with visual, aesthetic, historical-cultural, scientific and socio-economic values, is the development of geomorphotourism. This type of tourism is well demanded especially in developed industrialized countries. However, it is largely underestimated and undeveloped in Kazakhstan due to insufficient information, while there are many forms and types of landscape that potentially have natural, cultural and historical values. This paper based on sitevisits of geomorphic landforms of the Mangystau region in Kazakhstan have been reviewed and discussed the geomorphotourism potential of some of the geomorphosites of studied area. The geographical review shows that the landscape of the Mangystau region has the higher capability to develop ecotourism and geomorphotourism. Therefore, development of tourism in the study area is depending on the level of management and investment and further work under UNESCO Geoparks development programme on preserving the natural environment and sustainability of the tourism resources of the region.
\end{abstract}

Key words: landscape, geomorphotourism, geoparks, Kazakhstan

\footnotetext{
* Corresponding author
} 


\section{INTRODUCTION}

Natural factors have a spatial differentiation, both within the territory of Kazakhstan and in favourableness for the development of local economy, tourist and recreational activities. One of the most significant natural factors is the landscape (Kruzhalin et al., 2004). The geomorphological features of natural systems other regions of the world. Their territorial combination determines the degree of significantly affect the nature of recreational activities, because the landscape is a basic element natural complex. In addition, the landscape determines the recreational specialization of the territory, and in some cases is the main element in the formation of recreational systems (Bredikhin, 2004; Agakishieva, 2015). The attractiveness of the landscape for tourism is characterized by a number of its properties including stability, uniqueness, diversity, landscape attractiveness, cultural, historical and tourism values (Borsuk \& Timofeev, 2000). There is some experience in assessing the impact of the landscape on the formation and functioning of various types of territorial touristrecreational systems (Coratza \& Giusti, 2005). These include recreational-therapeutic, recreational, recreational-sports and recreational-cognitive type, considering the basic position of the landscape in the natural complex (Bredikhin, 2010). Geomorphotourism characterizes the aesthetic, cognitive value of the landscape associated with the earth's surface and their forms and complexes (Kurt \& Ekinci, 2013). Geomorpho-tourism is developed on the curiosity of people who were interested in the unique nature, landscape aesthetics, the original culture and history of the area.

Geomorpho-tourism includes such landforms as canyons, caves, rocks, outcrops, basins, in contrast to geotourism (geological), which includes the formation of various minerals, sediments, remains of exposed rocks, and rock outcrops on the day surface (Ekinci \& Doğaner, 2012). Natural territories or the terrain in relation to tourism should be considered as geomorphological features in context of attractiveness, uniqueness, landscape diversity and historical and cultural value (Bredikhin, 2003) being an object not only of scientific tourism (Koshim et al., 2019), but also geomorphotourism. A landscape with higher scientific, aesthetic and cultural values in geomorphotourism is called "geomorphosites", about which there are enough publications in the scientific world (Panizza, 2001; Coratza \& Giusti, 2005; Reynard et al., 2007; Coratza et al., 2008; Panizza \& Piacente, 2008, Comănescu \& Dobre, 2009; Necheş, 2013). The conservation status of large territories, which include various geomorphosites and geosites, is known as geoparks (Pereira et al., 2007; Necheş, 2013; Gavrilă \& Anghel, 2013). At present, geomorphosites are grouped by structural forms, such as volcanic forms, karst forms and coastal forms, morphoclimatic forms, as well as by individual elements such as canyons, lagoons, rocks, caves, ravines, slopes, and others (Panizza, 2001). Therefore, it is necessary to analyze these landforms from a geographical point of view, classifying them as objects of geomorphological tourism, using a simple classification as the most beautiful cave, the most beautiful fairy-tale rock or the most beautiful cliff (Pralong \& Reynard, 2005; Kurt, 2015).

According to the classification provided by Bredikhin (2010), the landscape of the Mangystau region refers to the recreational and geomorpho-tourism, which is determined by the use of geomorphological objects. The natural conditions of the Mangystau region, due to their geographical location and historical development, with unusual landforms, desert terrain, picturesque views of remnant mountains, canyons and gorges, ravines, dunes and sandy beaches, have a great potential for the development of geomorphological tourism in the region (Kondybay, 2005), however, a more detailed analysis of geomorphological conditions is needed. 


\section{MATERIALS AND METHODS}

\section{Study area}

The case study of research is the landscape of the Mangystau region. Mangystau means "the land of thousands winter huts". Mangystau is situated in the west of the Republic of Kazakhstan in an arid zone it occupies the territory on the shore of the Caspian Sea, embracing part of the Mangystau peninsula and Tupkaragan peninsula. The largest part of the territory is occupied by deserts and semi-deserts, interrupted by solonchaks and takyrs with wormwood vegetation and sparse bushes. There are no permanent rivers on the territory and the whole Mangistau region suffers from a deficit of water resources. The desert climate prompts the formation of a typical desert relief, with markedly pronounced erosional and aeolian processes. The relief of the territory varies considerably. The PreCaspian depression occupies the north-west of Mangistau region. The majority part of the plain is below ocean level (from o to $-28 \mathrm{~m}$ ), but towards the north-east and east it rises a little (from o to $100 \mathrm{~m}$ ). In the east the Pre-Caspian depression borders the remnants of the Ustirt northern escarpment with absolute elevation mark up to $152 \mathrm{~m}$ in the southeast it is abuts with the Ustirt western escarpment, which is composed of monadnocks more than $200 \mathrm{~m}$ high and in the south it borders the Mangystau upland. The southern part of the depression adjoins the Mangystau peninsula. The relief of this part of the territory is complex and contrasting along the boundaries of the oblast and Mangystau plateau there are some drainless solonchak depressions, the floors of which are considerably below sea level: Karakiya $(-132 \mathrm{~m})$, Kauyndy $(-57 \mathrm{~m})$ and Karynzharyk ($52 \mathrm{~m})$. From the north-west to the south-east of the Mangystau upland there are three prominences they are the ridges of the western and eastern Karatau and Karataushyk.

North and south of the western Karatau run ridges, formed of limestones, called the northern and southern Aktau (Aktau means "white mountains" and Karatau - "black mountains") their altitude is no more than $500 \mathrm{~m}$ above sea level. Parallel to the Karatau range extend the cuesta ridges of the north and south Aktay, confined to the mega-anticlinal limbs and composed of Danian limestones. Their steep slopes rise 100$200 \mathrm{~m}$ above the pre-Karatau valleys. Gentle slopes $\left(10-12^{\circ}\right)$ of the same dip give way in the southern Aktau to the Mangystau upland, while in the northern Aktau they fall towards the marine plains of the Bozashchy peninsula. The Karatau's tectonic ridgy relief as well as the spur-dome-like and small cuesta hills formed by selective denudation east of Karatau, are characteristic of hummocky topography.

The Mangystau mountains have a lot of picturesque examples of desert weathering. Gigantic (up to 5,5 m) ball-like concretions made of Albian-Cenomanian sandy deposits, 'air castles", fantastically deflated exposures of chalk, "mushroom rocks', columns, etc. can be seen there. Among the accumulative types of relief in lowland Mangystau one aeolian one predominates in the outcrops of sandy chalk rocks. Low-ridgy, isolated rare barckhan dunes cover hundreds of square kilometres southeast of the Karatau range. Inclined and concave deluvial-proluvial surfaces with sors in the hollows are widespread. The major part of the plain area is composed of sediments from marine encroachments of the ancient Caspian sea that created an original marine plain. Across vast territories of the region the relief has been transformed by desert agents, especially by the wind. Aeolian forms of relief such as the sandy massifs of Kyzylkum, Sum, Karynzharyk, etc., are widespread on the territory of Mangystau region. A specific feature of the Mangystau plain is non-draining depressions with precipitous rims $100-150 \mathrm{~m}$ deep their areas range from 10 to $200 \mathrm{~km} 2$. They are situated in two sublatitudinal rows, parallel to the main geological structures of the platform's cover and often coincide with local anticlines. There is good reason to believe 
that tectonic jointing of armed limestones contributes to the development of karst processes and the subsequent deepening and expansion of basins caused by desert denudation, resulting in the formation of depressions. In the walls of all the depressions and Mangystau border scarps steep slopes karst-erosional ravines, collapses and landslides are common. On the coast limestone karst grottoes, overhangs and caves are widely met. On the Tupkaragan peninsula in karst holes small lakes and streams of fresh water are formed exotic valleys of Tamshaly and Sauyr, which are attractive for tourists.

The climate of the territory is continental. The Caspian Sea has a significant impact on the temperature regime of the region. In general, winter is rather warm, short, with often thaws in the south of the region. The average temperature in January is $-4^{\circ}-9^{\circ} \mathrm{C}$, but sometimes it reaches $-26^{\circ}-43^{\circ} \mathrm{C}$. Summer is hot and long, the average July temperature is not lower than $24^{\circ} \mathrm{C}$, the maximum $-45^{\circ} \mathrm{C}$. The annual rainfall is $100-150 \mathrm{~mm}$. The region is characterized by strong storms and winds. Mangystau is the only region where there is no permanent river network. Drainage basins are widely distributed here, surrounded by a large number of dry channels, canals, ravines, in which surface runoff occurs in spring and autumn. The largest number of dry channels, wells, springs are in the mountainous part of Mangyshlak, the waters of some springs are so plentiful that they are used for irrigation of vegetable crops (Kondybay, 2007). The lakes are bitterly salty; in the summer, they dry up, leaving salt mud in the deepest parts and they are located mainly in drainage hollows.

\section{Methodology}

To write the article, mainly materials from long-term field research were used (20012002, 2008, 2012-2014, 2017). Statistical, reference, stock and literary materials on the natural conditions and resources of the region were also used (Kovshar, 1993; Safronova, 1996; Kim, 1997; Bekzhanov et al., 2000; Kondybay, 2005, 2007) and materials were studied from the regional department of ecology (https://eco. mangystau.gov.kz), the regional department of natural resources and environmental management (https:// www.inaktau.kz). Descriptive, comparative-geographical, statistical and cartographic research methods are used to characterize the geomorphological forms of the landscape of the territory. In addition, a set of complementary methods was used: information retrieval, analysis and systematization of scientific publications and materials on the object and subject of research. The methodological basis of the work was theoretical research on morphostructural analysis, developed by Rantsman (1979), according to the morphometric analysis of Anisimov (1999), using GIS-technologies by Antiptseva \& Doolit (2009), Zagorulko (2003). Assessment of the recreational opportunities of the territory was carried out according to the method developed by Kolotova (1998) and Bredikhin $(2004,2010)$.

To study the laws of morphological differentiation of the surfacerelief of the territory, one of the methods traditional for geomorphology was used - the method of analyzing the morphological features of the surface (morphological method), based on the study of the external features of the relief (Penk, 1961), determined by their parameters (dimensions, absolute and relative heights, the steepness of the slopes, the degree of erosion partition), which allows to clarify (establish) the similarities and differences between the same types and complexes of relief forms, about claimed regional and local features of endo- and exogenesis (Schukin, 1960). In addition, foreign publications on the organization of geomorpho-tourism were analyzed, where the topography is considered as a touristrecreational potential of the area (Panizza \& Piacente, 1993; Pralong, 2005; Pereira et al., 2007; Coratza \& Giusti, 2005; Ilies \& Josan, 2009; Ekinci \& Doğaner, 2012; Kurt \& Ekinci, 2013; Gavrilă \& Anghel, 2013; Kutr, 2015; Ovreiu et al., 2019). A geomorphological map of 1:2 000 o0o scale was compiled for the entire territory of the Mangystau region, which made it possible to identify patterns of spatial change in the relevant indicators. 
Landscape of the Mangystau Region in Kazakhstan as a Geomorphotourism Destination: A Geographical Review

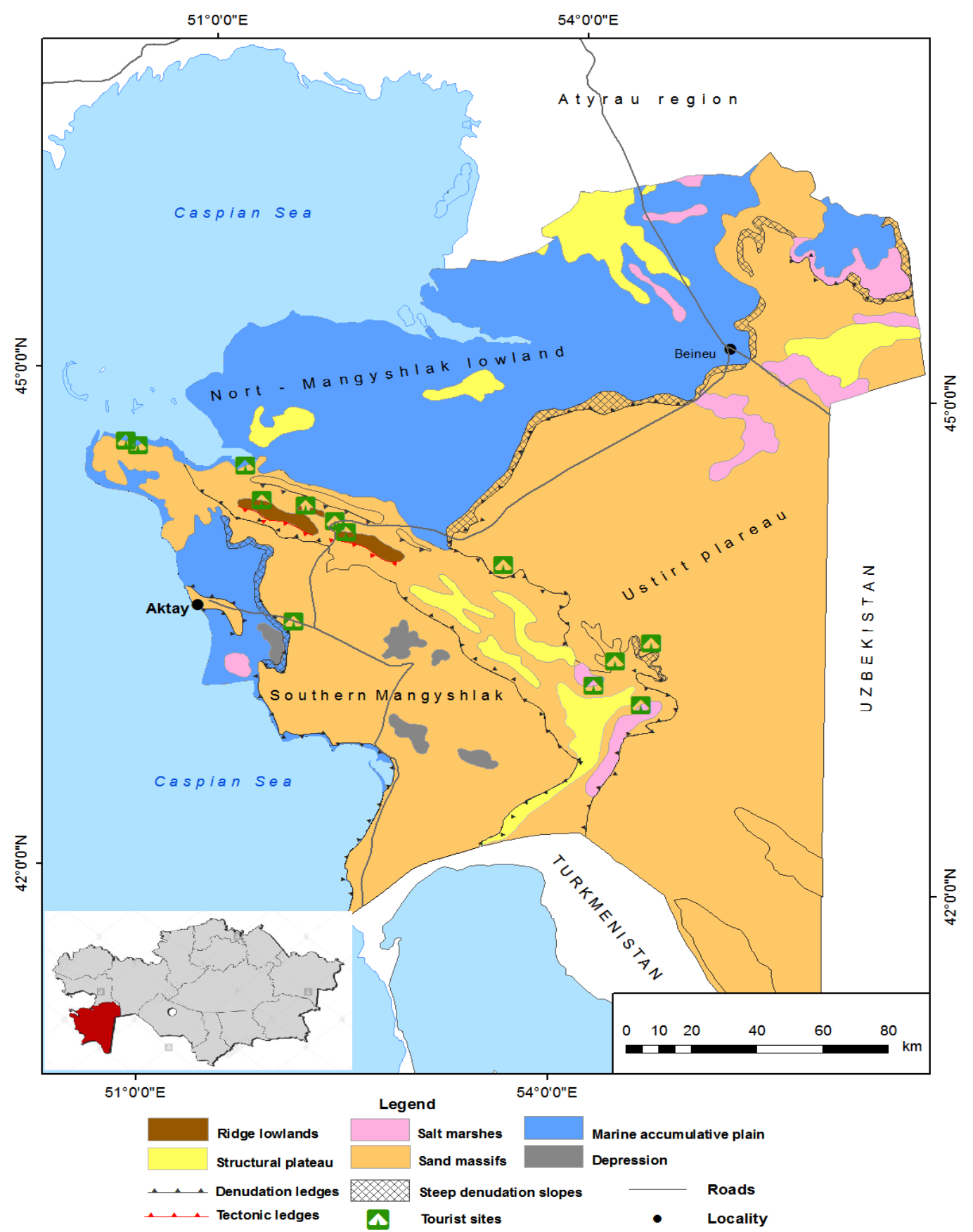

Figure 1. Geomorphological map of the Mangystau region

The results of studying the morphological features of the relief, taking into account published materials on geology, geomorphology of the study area, allowed us to analyze the features of the formation of various types and forms of relief (Aristarkhova, 1970, 
2015; Kuznetsov, 1963; Geldyeva \& Veselova, 1992, Sydykov et al., 1995; Relief of Kazakhstan, 1991). The features of the formation of the corresponding morphosculpture within each of the main morphostructures were clarified during the compilation and analysis of the geomorphological map of the region. When creating the map, data were used on the morphological structure of the territory (Relief of Kazakhstan, 1991, Geldyeva \& Veselova, 1992;), topographic maps (1:100,000, 200,000 scales), as well as data on the composition, occurrence conditions and age of the Quaternary sediment strata and bedrock (Koshkin et al., 2000) including field observation data (Figure 1). As it was said, the territory of the region is vast and the relief is unique everywhere. It was not possible to capture and study all geomorphological objects due to financial problems, therefore, the analysis was carried out only for those objects that are of most interest to tourists.

\section{RESULTS AND DISCUSSIONS}

Mount Sherkala Geomorphosite. The territory of the geotope Mount Sherkala is located about 170 kilometers from the city of Aktau, $18 \mathrm{~km}$ from the village (Figure 2).

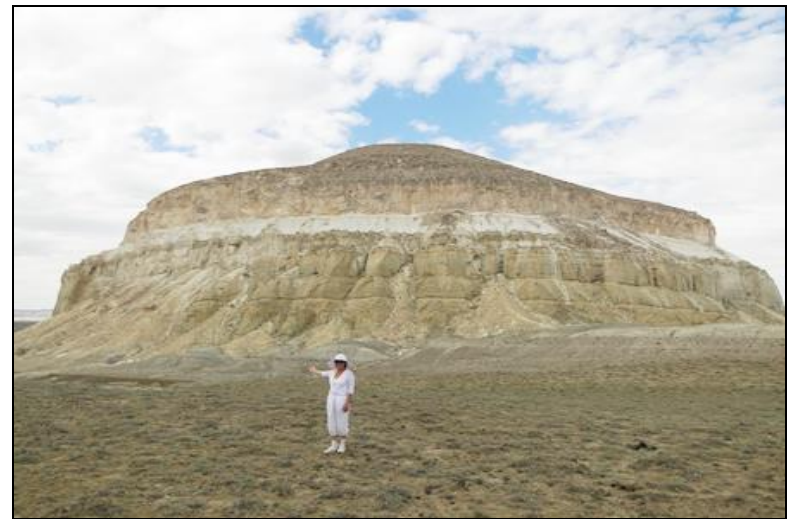

Figure 2. Mount Sherkala Geomorphosite
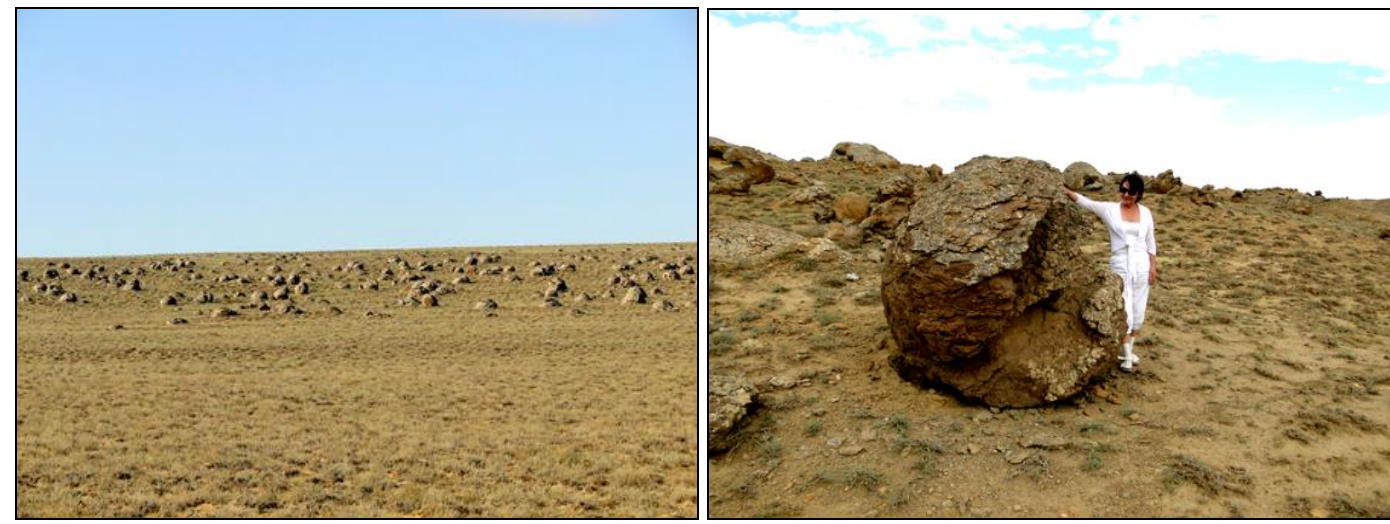

Figure 3. Torysh Geomorphosite

Shetpe to the north-west. In morphological terms, the table remains with a complex gully-relief relief. Mount Sherkala is a lonely standing mountain, of a very unusual shape. If you look at it from one side, the mountain looks like a huge white yurt 
(Nomadic house), but on the other - Sherkala is like a sleeping lion, who laid his huge head on his paws. Therefore, the mountain was named - Sherkala, which in translation from Turkmen means "Lion Mountain" or "Lion Mountain".

The Sherkala mountain is composed of sediments of the Upper Cretaceous, the Turonian stage, represented by grayishwhite, greenish-gray sandy marl, brown chalk-like marls, with a powerful horizon of white writing chalk that seems to encircle the mountain with a white scarf. Neogene Sarmatian clays gray layered calcareous, with interlayers of marls and siltstones, overlapping with dense light-gray limestone-shells armor the surface of the mountain (Bekzhanov et al., 2000). In the foothills and around the Sherkala Mountains, in the clay limestones of brownish yellow with an admixture of sandy material, clayey-sand deposits, the horizon of giant globular sand concretions is traced this is a whole placer of spherical boulders of various sizes limestone. Together with them there are small phosphorite nodules. This horizon of sandy concretions is a continuation of the horizon found in the tract Torysh. In the foothills of the mountain Sherkala there is an abundance of organic remains: large ammonoids. Here, too, bivalve mollusks, flora, microfauna, belemnites, teeth of sharks, oysters, bryozoans have also been found. Torysh Geomorphosite. The territory of Torysh Geomorphosite is located in the Northern part of Karatau valley of the Mountainous Mangistau (low mountains), to the northeast of the village Taushyk (Figure 3). Ball concretions, which are one of the recognized tourism brands of Mangystau, form entire fields in the Torysh tract - this place is called the valley of spheroit concretions. Sandy concretions are confined to the clayey-sandy thickness of the Lower Cretaceous of the Albian stage (K1al), developed in the "Kara-Tatau" valley. Along with them, there are layers of nodules of phosphorites everywhere.

Nodules are found both in the form of a regular globular shape, discoid, and the most varied and bizarre contours, often reaching gigantic dimensions up to 3-5 meters in diameter. There are many theories and assumptions about the origin of these formations, sometimes the most fantastic ones. One of the scientifically valid theories is the formation as a result of chemical deposition of matter. Any formation, for example, fossilized remains, accumulations of other minerals, carbonaceous matter, etc., can serve as the nucleus of a "seed" around which silica, calcite and other substances, in this case sand material, precipitate. This accumulation takes place in a concentric direction, and the shape of the formations depends on the permeability of the rocks. If the rock shows the same permeability in all directions, then the formations will have a regular rounded shape, if in two directions - they will have the shape of a disk, in the case of uneven permeability very fancy shapes will be formed. The formation of concretion can also occur because of the diffusion contraction of the chemical substances to the nuclei that activate this process-the "seeds." Fauna is mainly confined to nodules, sandy interlayers and interlayers with nodules of phosphorites: ammonites, oysters, sea urchins, belemnites, teeth of sharks.

The North Mangyshlak Lowland (or the Bozashi Peninsula) is located below the horizontal zero and is represented by a marine accumulative plain composed of clay, loamy and sandy sediments with interbeds of shell. In Quaternary, it was again flooded with the sea, which left an almost continuous, thin, 10-15 m thick layer of precipitation. Here, under the cover of the Quaternary marine sediments, more ancient, undiluted, Cretaceous, and Paleogene deposits lie (Bekzhanov et al., 2000). Typical elements of the relief are sand massifs, deflation basins, funnel-shaped basins, basins, takyrs, solonetzes (white alkali) and solonchaks (saline land), as well as cellular, tuberous and ridged sands, which were formed as a result of eolian processes (Sydykov et al., 1995). The absolute elevations of the plain surface vary from -7 to $-27 \mathrm{~m}$, decreasing towards the sea. Within this region, oil and gas are mainly being developed (Koshim \& Karatayev et al., 2018). 
Mangyshlak Mountain is represented by low ranges of the North and South Aktau, Western and Eastern Karatau. The Karatau ridges are composed of dislocated sandstones, mudstones, schists, Permo-Triassic limestones and conglomerates represented by large ridges with leveled or slightly wavy peaks and steep, sharply dissected slopes (Bekzhanov et al., 2000). The ranges are facing the Karatau valleys and rise above them by 100-200 m. The highest point of the town of Beshoky is $556 \mathrm{~m}$, in East Karatau. Deposits of greenish clays at the foot merge with yellowish, pink, reddish clays or snow-white chalky outcrops; above they turn into yellowish-brown Sarmatian limestones. All of this is represented by a unique, layered formation, because the strata of deposits of unequal density and are susceptible to erosion in different ways (in particular, the layering of rocks is clearly visible on the coast). In Northern Aktau there is a unique place called "Akespe" (Figure 4). It is also called the "chess valley" because of the location of the rocks. The area is distinguished by a peculiar whiteness due to stacked rocks: limestones, marls and snow-white clays. Due to wind erosion, a typical type of relief has formed here, giving the area a beautiful landscape. The peaks of low snow-white mountains are cut by ravines and hollows. In the spring, during rain, stormy streams run along them, sometimes demolishing roads and settlements.
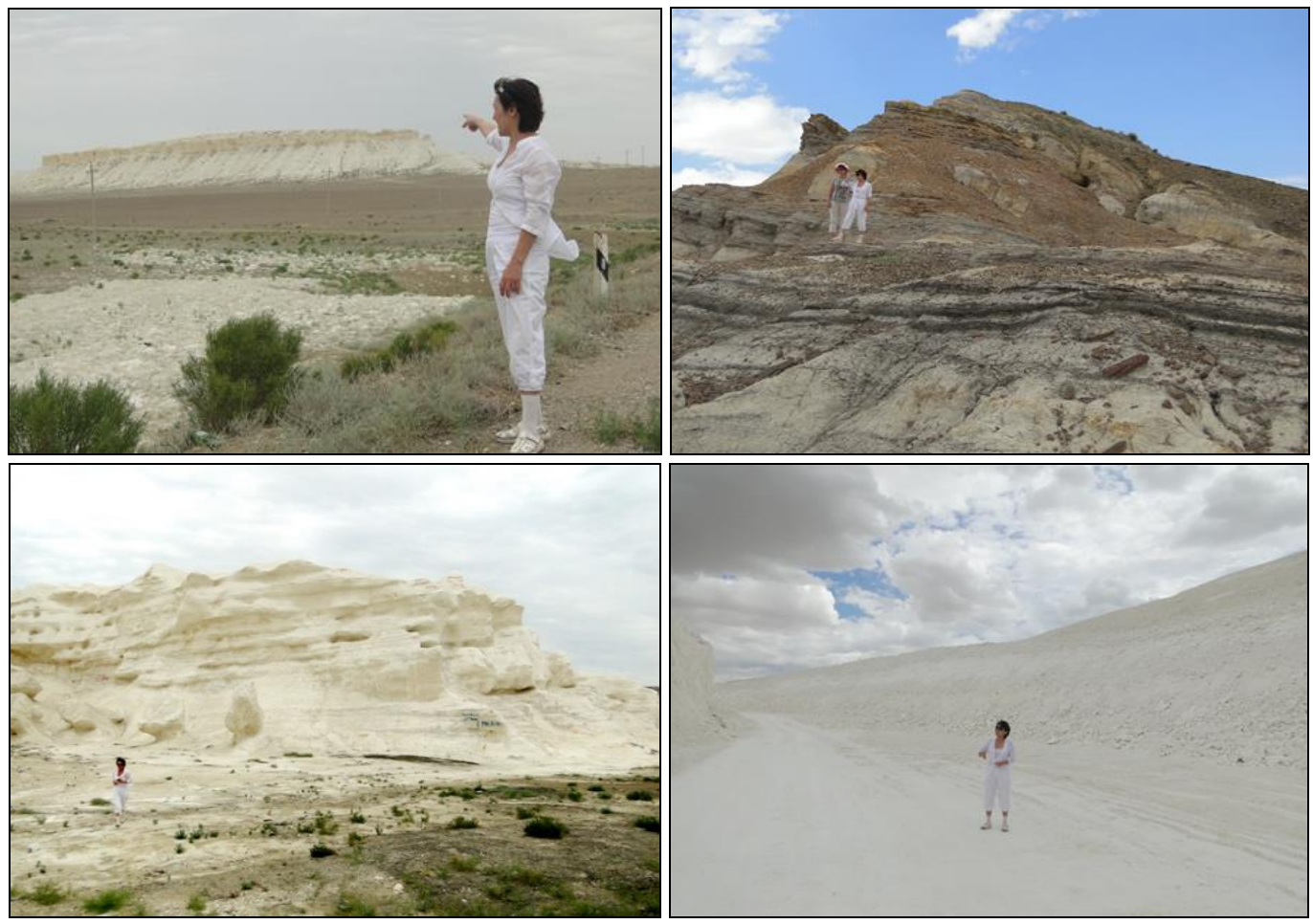

Figure 4. Mountain Mangyshlak Geomorphosites

On the expanses of the Steppe Mangyshlak there are several drainless basins. One of them is Karakia, the third deepest trench in the world (Figure 5). The name of the basin is Turkic, in translation it means "Black Maw" and it is located 132 meters below sea level and 100 meters below the waves of the Caspian Sea. The basin is $40 \mathrm{~km}$ long and $10 \mathrm{~km}$ wide. A highway runs through a wide part of the basin $(15 \mathrm{~km})$. The surface 
of this part is covered mainly with sand. Litter is located at the bottom of the cavity, the descent to which is hampered by deep steep and winding ravines. The Eastern slope of the basin is high and cut through by deep ravines. According to local tradition, a long time ago there was a lake on this place, which was called "Batyr" - "Brave Warrior". The lake gradually dried up and a hollow formed. Locals still call basin as the "Batyr" basin. The formation of a basin is associated with the leaching of salty rocks, with subsidence and karst processes (Aristarkhova, 1970). The karst is based on the erosive and dissolving activities of groundwater. Underground water seeping to the bottom of the cracks found in limestone, dolomite and gypsum, gradually dissolved the rocks, expanded them, developed deep and narrow abysses (Kondybai, 2007).
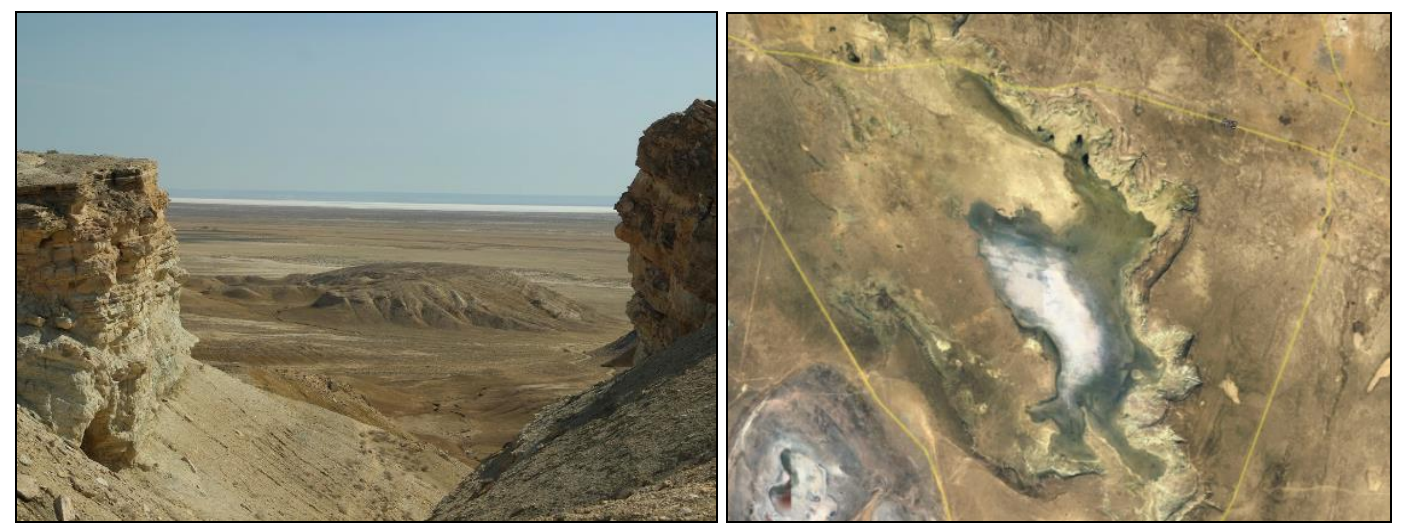

Figure 5. Karakiya Basin Geomorphosite

The Ustirt Plateau or East Mangyshlak is a desert plain composed of Sarmatian limestones, overlain by clay and clay-gravel, and sand deposits in some places. The relative heights of the Northern chinks are from 100 to $300 \mathrm{~m}$, in the Shagraysky plateau region they drop to $50 \mathrm{~m}$. (Figure 6). The height of the Northwestern and Western chinks often reaches $200 \mathrm{~m}$, where it cuts off Muzbel rock to Karynzharyk litter - $340 \mathrm{~m}$. In the Northeast, the chinks are already smoothed, with a slope of up to 10-150, and in other cases their overall steepness is about 500 and a height of up to 300 meters. In most of the plateau, the upper part of the chinks is as if visually separated from the bottom by a sheer or even overhanging view (the height of the upper part is up to $1 \mathrm{~m}$ ). The structure of the lower part of the chinks is different. In the Northern chinks, this is a flattened ledge with a continuous proluvial train at the sole, cut by small erosive forms. In the Northwest, the chinks have a stepped structure due to large settled blocks, with an abrasion ledge below. In the West, often in the forerunner strip up to 1-3 $\mathrm{km}$ wide, a fanciful multi-colored ravinelandslide-remnant relief is formed (Aristarkhova, 1970). Climbing the plateau is possible only in a few places where there are specially laid trails. The pride of the chinks is also explained by the fact that it was on the slopes of the chinks that at one time all the ancient mosques of saints were built (there are more than 300 of them). One of the famous mosques - Becket Ata, is located on the slope of the Northern clink of chalk rocks (Figure 6).

The Boszhira Geomorphosite is also considered the main feature of the relief of the plateau - it is a remnant mountain range on the outskirts of the Western Ustyurt cliff, where the plateau abruptly ends with a cascade of clay-limestone steps, occupying the bottom of a large canyon-basin Karashek. The eponymous litter is located in the Southwest of the Boszhira tract. The Boszhira tract occupies a huge area, with a length 
of 21 kilometers from North to South and 9 kilometers from East to West. Boszhira's cosmic landscapes are composed of limestone deposits, once the bottom of the ancient Tethys Ocean, which existed over 10 million years ago. The huge valley-hollow is surrounded on three sides by an "amphitheater" of various landforms of white Cretaceous rocks - canyons, peaks, mountain-towers, mountain-castles (Figure 7).
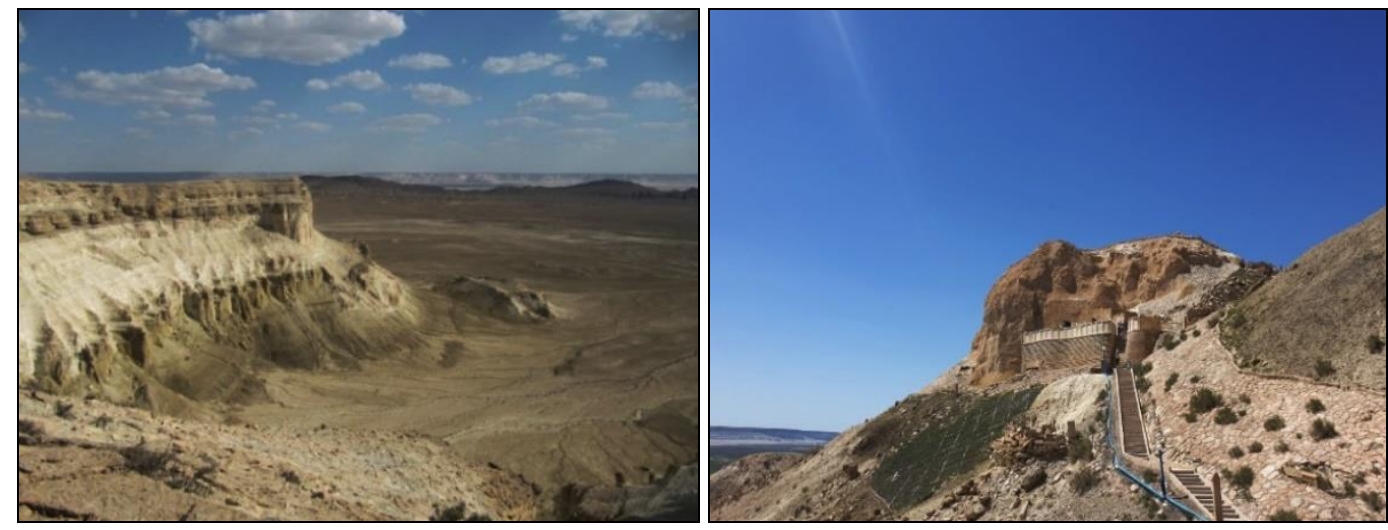

Figure 6. Ustirt chinks and the Becket Ata necropolis
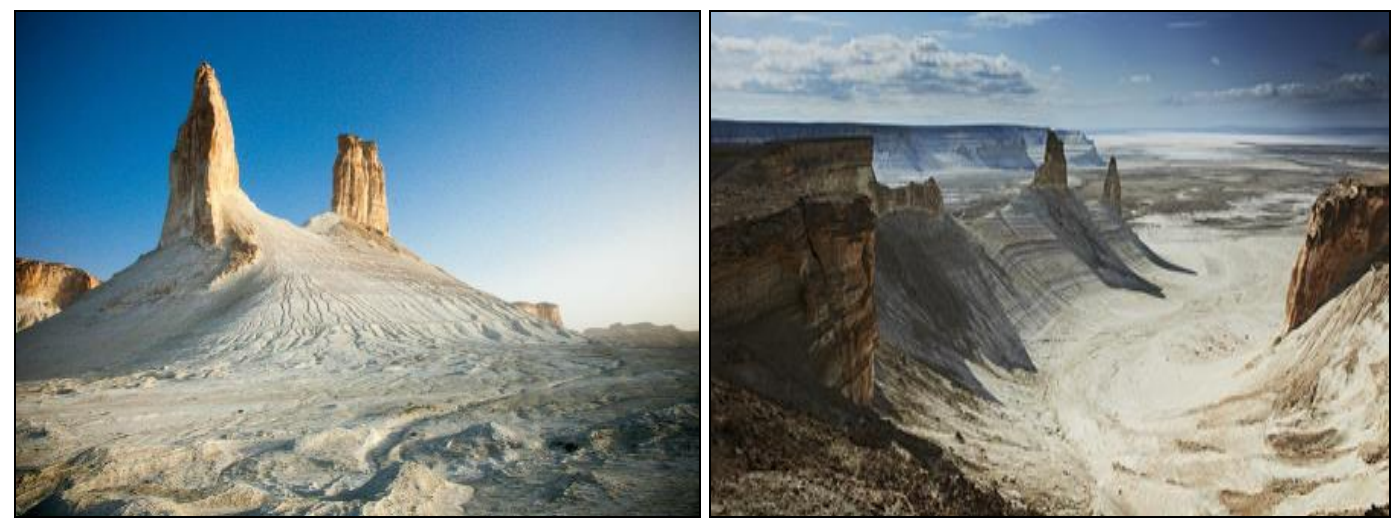

Figure 7. Boszhira Geomorphosite

Outlier mountains-chameleons also formed here, changing their appearance depending on the position of the sun and the time of day, a mountain-yurt, rocky gorges with steep walls, eroded chalk strata, stone nodules. At the bottom of the hollow you can find petrified shells and teeth of ancient sharks. A feature of Boszhira are two limestone peaks, about 300 meters $(287 \mathrm{~m})$ high, nicknamed for their form the "Azu Tister", translated from the Kazakh "Fangs of Ustirt". The peaks are cut by small ravines and beams, between which there is a narrow path along which you can climb to the observation deck from which a wide view of the Boszhira valley opens.

Thus, Ustirt is the largest geomorphological element of the earth's surface, which, like the Great Barrier Reef, is clearly visible from space. However, in its structure and geological history, it is more interesting than the famous Australian structure. The total length of the chain of chinks is several hundred kilometers, which makes it possible to develop geomorpho-tourism in this region and create geoparks. 
The geomorphosites described above have great scientific value. For example, departments of geology of leading universities organize student's practicum at these sites. International expeditions are carried out in Mangistau for its unique geological features and good condition, i.e. the spheroid concretions. The aesthetic value of the territory attracts up to 25 thousand tourists per year. Currently the geological sites do not have legal protection. However, an Atlas of unique sites is being developed by the Institute of Geography. Based on the findings a protected regime will be proposed for the government. A Master plan was developed for the promotion of geopark and its activities. Analysis of geotourism potential of the proposed Geopark Overview and policies for the sustainable development of: A new policy for sustainable development in line with the Government of Kazakhstan "Transition to Green Economy" directive is being implemented by the Akimat of Mangistau region.

\section{POLICIES FOR GEO-TOURISM DEVELOPMENT}

An important area of work of public organizations responsible for development tourism at local level is the creation specific programs, which include:

- political, legal and methodological support, establishing a legislative framework for the regulation of tourism and based on a comprehensive program for the strategic development of tourism at local level, taking into account the competitive advantages and disadvantages of recreational territories (the program should be based on scientific and systematic approach that organically includes a recreational, economic, marketing, investment, social, environmental and political components);

- financial and investment support (including possible sources of support, methods of accumulation and directions for effective use on the basis of existing and newly created credit structures);

- organizational and consulting and advertising and informational support for the promotion of tourism, the formation of a database of tourism companies, round tables and explanatory work with the population, its training, and the dissemination of best practices of leading travel agencies and tourism farms;

- development of rural infrastructure (roads, land improvement and development of territories, etc.) based on private-state partnership (for example, the provision of a soft loan by the state for a long term to improve rural roads by entrepreneurs and tourism farms).

It is advisable to provide staff units in public organizations for specialists in the development of recreation tourism. Such a specialist should analyze the state and problems of the development of the tourism industry; advise and inform tourism business entities on a wide range of issues of interest to them; supervise for compliance with tourism legislation, participate in the development of regional programs and pilot projects for the development of tourism; organize regional and international scientific and practical seminars and symposia on tourism development, as well as tourism exhibitions, fairs, exchanges, etc. Important conditions for the formation of effective and sustainable tourism in the regions of Kazakhstan, including the Mangistau region, are strategic planning and forecasting of integrated development territories, marketing, the use of foreign experience, and most importantly the interested participation of the local population and local authorities in the formation of tourism in the region, their joint coordinated activities. Finally, Kazakhstan can use some international initiatives to develop local tourism, e.g. geoparks. Unfortunately, today there is not a single geopark in Central Asia, therefore the Kazakhstan National Committee for UNESCO Global Geoparks, which was created in 2017, will contribute to the development of the concept of geoparks in Kazakhstan and promotion of the 
UNESCO International Geoparks Program in the country. According to the UNESCO National Committee on Global Geoparks, at least 40 geoparks can be created in the republic and, in this case, the first geopark may be the landscape of Mangystau.

\section{CONCLUSIONS}

Mangistau region has a great potential for geotourism due to its geographical location (closest point of the country to Europe and North America, Turkey, Azerbaijan etc.), international and national flights to major cities, commitment from the regional municipality for investing in infrastructure, the only marine port in the country, attractive landscapes and geotourism activities (biking, fishing, diving, paragliding etc.)

The significant diversity of the landscape of Mangystau, in places the deep ruggedness of the ravines, the various expositions of the slopes with respect to the sun and air flows created a rare aesthetics of the territory's landscapes, which are one of the valuable natural heritage of not only the region, but the whole Kazakhstan.

Geomorphological relief types or geomorphosites of the region are unique objects, they have their own characteristics and advantages and, in comparison with other regions of the republic that do not have such a relief. The landscape of region is not only of protection, scientific research, but also of the development of geomorphotourism in the region. In the future, geomorphotourism could become a powerful and positive force that benefits both travelers and the environment.

It contributes to the revival of not only the flora and fauna of these territories, but also the restoration of the culture and traditions of the local population. If tourists visit certain places with interesting objects, then there is an incentive for local residents to preserve the uniqueness of the landscapes of these places. The development of geomorphotourism also opens up opportunities for the local population, providing them with work, increases the income of local entrepreneurs.

\section{REFERENCES}

Agakishieva, G.R. (2015) The role of relief in the organization of tourism in Azerbaijan. International scientific journal, № 5 (21), Vol. I, pp. 138-141.

Anisimov, V.I. (1999). Morphometric analysis of the relief. Sochi: Publishing House SGuTiKD,.321 p.

Antiptseva, Yu.A. \& Doolit, J.A. (2009). Morphometric analysis of the relief using GIS technologies to assess the recreational potential of the Lagonaki Highlands (North-Western Kazkaz). Geomorphology, No. 1, pp. 45-50.

Aristarkhova, L.B. (1970). Geomorphology of the Podural Plateau and the Caspian Lowland // Geomorphology of the USSR. T.21, p. 528-634.

Aristarkhova, L.B. (1970). Quaternary system of the Caspian basin. Geology of the USSR, v.21, Nedra, Moscow, pp. 811-839.

Bekzhanov, G.R., Koshkin, V.Ya. \& Nikitchenko, I.I. (2000). Geological structure of Kazakhstan - Almaty: Academy of Mineral Resources of the Republic of Kazakhstan, 396 p.

Borsuk, O.A. \& Timofeev, D.A. (2000). Attractiveness as a criterion of aesthetic geomorphology, in: Geomorphology at the turn of the 21st century, Publishing House of Moscow State University, Moscow, pp. 124-126.

Bredikhin, A.V. (2003). Relief as a condition and resource of recreational activities. Bulletin of Moscow State University, series Geography, № 1, pp.58-59.

Bredikhin, A.V. (2004). Recreational properties of the relief. Bulletin of Moscow State University, geography series, № 6, pp. 24-30.

Bredikhin A.V. (2010). Recreational and geomorphological systems. Smolensk: Oikumena, 328 p.

Comănescu, L. \& Dobre, R. (2009). Inventorying, evaluating and tourism valuatingthe geomorphosites from the Central sector of the Ceahlău National park. GeoJournal of Tourism and Geosites, 1 (3), pp. 86-96.

Coratza, P., Ghinoi, A., Piacentini, D. \& Valdati, J. (2008). Management of geomorphosites in high tourist vocation area: an example of geo-hiking maps in the Alpe Di Fanes, Natural Park of Fanes-SenesGéomorphologie: relief, processus, environnement, 3, 189-196. 
Coratza, P. \& Giusti, C. (2005). Methodological proposal for the assessment of the scientific quality of geomorphosites. Quaternario, 18 (1), pp. 307-313.

Ekinci, D. \& Doğaner, S. (2012). Simav (Yeniköy) Fairy Chimnesy Terms of Geomorphotourism, III, National Geomorphology Symposium, Proceedings, Hatay-Turkey, pp. 395-410.

Gavrilă, I.G. \& Anghel, T. (2013). Geomorphosites Inventory in TheMăcin Mountains (South-Eastern Romania). GeoJournal of Tourism and Geosites, 11(1), pp. 42-53.

Geldyeva, G.V. \& Veselova, L.K. (1992). Landscapes of Kazakhstan. Gylym, Almaty. 176 p.

Ilies, D. C., Josan, N., (2009), Geosites-geomorphosites and relief. GeoJournal of Tourism and Geosites, 1 (3), 2009, pp. 78-85.

Kim, A.G. (1997). Recreational assessment of the terrain and the development of tourist and recreational facilities in the Republic of Kazakhstan. Rauan, Almaty, 287 p.

Kolotova, E.V. (1998). Recreational Resource Management, RMAT, Moscow, pp. 134.

Kondybay, S. (2005). Aesthetics of landscapes of Mangystau: prospects for the development of tourism, Arys Publishing House, Almaty, $176 \mathrm{p}$.

Kondybay, S. (2007). Geography of Mangystau Tutorial. NurlyAlem, Almaty, 184 p.

Koshim, A., Karatayev, M., Clarke, M.L. \& Nock, W. (2018). Spatial assessment of the distribution and potential of bioenergy resources in Kazakhstan. Advances in Geosciences, 45, 217-225.

Koshim, A, Sergeyeva, A, Saparov, K. \& Wendt, J.A. (2019). Development of scientific tourism at Baikonur Cosmodrome Kazakhstan. GeoJournal of Tourism and Geosites, 24 (1), pp. 266-278.

Kovshar, A.F. (1993). Reserves of Kazakhstan. Science, Almaty, 264 p.

Kruzhalin, V.I., Simonov, Yu.G. \& Simonova, T.Yu. (2004). Man, society, relief: Fundamentals of socioeconomic geomorphology, Dialogue of cultures, Moscow, pp. 120.

Kurt, S. (2015). Thecoastsof Kapidag Peninsulain terms of geomorphotourism. GeoJournal of Tourism and Geosites, 1 (15), pp. 44-58.

Kurt, S. \& Ekinci, D. (2013). The Geomorphotourism Features of The North Coast of Gulf of Erdek, 3rd International Geography Symposium: GeoMed, pp. 450-46o.

Kuznetsov, Y. (1963). Caves of Ustyurt, in: Proceedings of Samara University, New serria. № 134, pp. 79-88.

Necheş, I.M. (2013). From Geomorphosite Evaluation ToGeotourism Interpretation, Case Study: The Sphinx Of Romania's Southern Carpathians. GeoJournal of Tourism and Geosites, 12(2), pp.145-162.

Ovreiu, A.B., Bărsoianu, I.A., Comănescu, L. \& Nedelea, A. (2019). Capitalizing of the geotourism potential and its impact on relief Case study: Cozia massif, Romania. GeoJournal of Tourism and Geosites, 24 (1), 2019, pp. 212-236.

Panizza, M. \& Piacente, S. (1993). Geomorphological assets evaluation, Z. Geomorph. N. F., Suppl.-Bd. 87, 13-18.

Panizza, M. (2001). Geomorphosites: Concepts, Methods and Examples of Geomorphological Survey. Chinese Science Bulletin, 46, pp. 4-6.

Panizza, M. \& Piacente, S. (2008). Geomorphosites and Geotourism, Revista Geográfica Acadêmica, 2(1), pp. 5-9.

Penk, W. (1961). Morphological analysis, Geografgiz, Moskow, pp. 359.

Pereira, P., Pereira, D. \& Alves, M.I.C. (2007). Geomorphosite Assessment in Montesinho Natural Park (Portugal). Geographica Helvetica, 62(3), pp. 159-168.

Pralong, J.P. (2005). A method for assessing tourist potential and use of geomorphological sites, Géomorphologie: relief, processus, environnement, 3, 189-196.

Pralong, J.P. \& Reynard, E. (2005). A proposal for the classification of geomorphological sites depending on their tourist value, Quaternario, 18 (1), pp. 315-321.

Rantsman, E.Ya. (1979). Places of earthquakes and morphological structure of mountainous countries, Nauka, Moscow, pp. 270.

Reynard, E., Fontana G., Kozlik, L. \& Scapozza C. (2007). A method for assessing «scientific» and «additional values» of geomorphosites. Geographica Helvetica, 62 (3), pp. 148-158.

Safronova, I.N. (1996). Deserts of Mangyshlak, St.Petersburg: BIS, 210 p.

Schukin, I.S. (1960). General geomorphology, Publishing House of Moscow State University, Moskow, pp. 615.

Sydykov, Zh.S., Golubev, V.V. \& Kuandykov, B.M. (1995). The Caspian Sea and its coastal part (natural conditions and ecological status), Olke, Almaty.

Zagorulko, V.A., Khamarin, V.I. \& Tyabaev, A.E. (2003). Morphometric analysis of the relief by means of GIS technologies (on the example of the Seminsky pass), Geomorphology, № 4, pp. 40-46.

*** Relief of Kazakhstan, (1991). Explanatory note to the geomorphological map of the Kazakh SSR on a scale of 1: 1,500,00o. Parts 1 and 2. - Almaty: Gylym, Part 1 - 168 p., pp. $2-176$.

https://eco.mangystau.gov.kz /The official website of the Department of Natural Resources and Environmental Management of the Mangistau Region. Date of appeal: November 2019.

https://www.inaktau.kz). Department of Ecology in the Mangystau region. Date of appeal: November 2019.

Submitted:

06.12.2019
Revised:

24.03.2020
Accepted and published online 01.04.2020 